\title{
類天疱瘡 14 例の診断・治療に関する検討
}

\author{
鎌口真由美 $^{1)} \cdot$ 浅 香卓 哉 $^{1)} \cdot$ 山下映 美 $^{1)}$

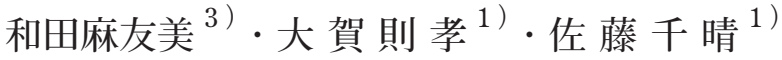 \\ 佐藤 淳 $^{1)} \cdot$ 北村哲也 ${ }^{2)}$ \\ 進藤正信 ${ }^{2)} \cdot$ 北川善政 ${ }^{1)}$
}

\section{A study of diagnosis and treatment in 14 patients with pemphigoid}

\author{
KAMAGUCHI Mayumi $^{1)} \cdot$ ASAKA Takuya $^{1)} \cdot$ YAMASHITA Emi $^{1}{ }^{1}$ \\ WADA Mayumi $^{3)} \cdot$ OHGA Noritaka $^{1)} \cdot$ SATOH Chiharu ${ }^{1)}$ \\ SATO Jun $^{1)} \cdot$ KITAMURA Tetsuya $^{2)}$ \\ SHINDOH Masanobu ${ }^{2)} \cdot$ KITAGAWA Yoshimasa $^{1)}$
}

\begin{abstract}
Bullous pemphigoid (BP) and mucous membrane pemphigoid (MMP) are autoimmune subepidermal blistering diseases caused by autoantibodies against basement membrane proteins. BP is clinically characterized by tense blisters within the basement membrane zone of the skin. The mucous membranes are also affected in $10 \%$ to $20 \%$ of patients with BP. In contrast, MMP predominantly affects the mucous membranes. The skin is involved in 25\% to $35 \%$ of patients with MMP. These patients present to oral surgery institutions because of the onset of oral manifestations as initial symptoms.

We clinically studied 14 patients who presented to our department and were then given a diagnosis of BP (4 patients) or MMP (10 patients) in cooperation with dermatologists between May 2012 and March 2016. Among the 14 patients, $75 \%$ of the BP cases and $50 \%$ of the MMP cases were correctly diagnosed on the basis of the clinical findings, histological analysis, and the detection of IgG autoantibodies against BP180NC16A in sera on enzyme-linked immunosorbent assay. Because oral mucous lesions in pemphigoid diseases seldom show typical blister formation, we need to consider differential diagnoses of oral mucous diseases. On the other hand, direct immunofluorescence (DIF) and indirect immunofluorescence (IIF) led to a definitive diagnosis in $100 \%$ of the patients with BP and $80 \%$ of the patients with MMP. DIF and IIF were performed promptly in cooperation with dermatologists in our hospital and enabled early diagnosis in nearly all patients, thus facilitating the early initiation of treatment. In the dental department, we continued oral examinations and management. We endeavored to assess treatment efficacy, choose topical agents, and maintain oral hygiene. Lesions consequently improved in all patients. This study indicated that DIF and IIF were beneficial in definitively diagnosing BP and MMP. Oral surgeons should be familiar with the characteristics and clinical findings of BP and MMP to facilitate the diagnosis and treatment of these diseases.
\end{abstract}

1) 北海道大学大学院茵学研究科口腔病態学講座口腔診断内科 学教室

(主任：北川善政教授)

${ }^{2)}$ 北海道大学大学院茵学研究科口腔病態学講座口腔病理学 教室

(主任：進藤正信教授)

3) 社会医療法人北斗 北斗病院茵科口腔外科 （主任：牧野修治郎部長）

${ }^{1)}$ Department of Oral Diagnosis and Medicine, Division of Oral Pathobiological Science, Graduate School of Dental
Medicine, Hokkaido University (Chief: Prof. KITAGAWA Yoshimasa)

${ }^{2)}$ Department of Oral Pathology and Biology, Division of Oral Pathobiological Science, Graduate School of Dental Medicine, Hokkaido University (Chief: Prof. SHINDOH Masanobu)

${ }^{3)}$ Department of Oral Surgery, Hokuto Hospital (Chief: Dr. MAKINO Shujiroh)

受付日：2016年 9 月 4 日

採択日：2017 年 9 月 26 日 
Key words: bullous pemphigoid (水疮性類天疮瘡), mucous membrane pemphigoid (粘膜類天疮瘡), direct immunofluorescence (蛍光抗体直接法), indirect immunofluorescence (蛍光抗体間接法), enzyme-linked immunosorbent assay (ELISA 法)

\section{緒}

\section{言}

類天疮瘡は抗表皮基底膜部抗体により水疮形成を生じる 自己免疫性水疮症であり, 口腔内症状を呈するものは水疮 性類天疮瘡 (bullous pemphigoid, 以下 BP) と粘膜類天疮 瘩 (mucous membrane pemphigoid, 以下 MMP) に大別さ れる ${ }^{1,2)}$. BPは皮虞の掻痒性紅斑と緊満性水疮を特徴とし， 口腔粘膜病変の併発は全体の $20 \%$ 程度とされる ${ }^{3)}$. 一方, MMP は口腔粘膜や眼粘膜のびらんや水疮形成を特徵とし， 皮膚症状の併発は患者全体の 25 35\%である ${ }^{4,5)}$. 類天 疮瘡は口腔粘膜に初発し, 口腔外科を受診する例も散見さ れる. 口腔外科医としてその病態や臨床所見を十分に知り， 早期に鑑別診断を行い，皮膚科などの医科と連携すること により適切な治療を行う必要がある。しかし，本疾患は臨 床所見のみでは確定診断が困難であり，さらに類天疱痆の 主要な原因抗原である抗 BP180 抗体の検出率が MMP では 必ずしも高くないことはあまり知られていない4）。また， 本邦に打いて口腔外科領域からの類天疮瘡についてのまと まった報告はほとんどない

そこで今回，口腔内症状を主訴に当科を初診し，当院皮 膚科と連携し， BP および MMP の診断に至った 14 例につ いてその診断，治療に関する検討を行い，両疾患の臨床症 状や検査所見，診断に至るプロセスや治療における管理方 法について考察した。

\section{対 象・方 法}

2012 年 5 月から 2016 年 3 月に口腔内のびらんや潰瘍形 成等を主訴に当科を初診し，類天疱瘡の診断に至り治療・ 管理を行った 14 例を対象とした。当科にて皮膚や口腔内 病変打よび初発部位に対する問診と診査, 血液検查（抗 BP180NC16A 抗体 ELISA 法）を実施した。 ELISA 法にて 陰性となった症例も，その臨床所見から本疾患を含む自己 免疫性水疮症が否定できない場合は, 当院皮膚科と協議し， 蛍光抗体法, 病理組織学的検查打よび免疫ブロット法を施 行した.

蛍光抗体法は患者皮膚を用いる蛍光抗体直接法 (Direct immunofluorescence, 以下 DIF) と，患者血清を用いる蛍光 抗体間接法 (Indirect immunofluorescence, 以下 IIF) を実施 し,さらに $1 \mathrm{M}$ 食塩水を用いた split-skin IIF (以下 ssIIF) ${ }^{5}$ ) による評価が行われた。

類天疮瘡の診断基準についてはすべて，2015 年の Euro-
表 1 類天疮瘕の診断基準

$\mathrm{A}$ 臨床的診断項目

1。皮膚に多発する, 癌痒性紅斑。

2，皮膚に多発する，緊満性水疮打よびびらん。

3 . 口腔粘膜を含む粘膜部の非感染性水疮打よびびらん。

B検查所見

1. 病理組織学的診断項目

1）表皮下水疮を認める.

2 . 免疫学的診断項目

1）蛍光抗体直接法により,皮膚の表皮基底膜部に $\mathrm{IgG}$, あるいは補体の沈着を認める。

2 ) 蛍光抗体間接法により, 血中の抗表皮基底膜部抗 体 (IgG) を検出する。あるいは ELISA (CLEIA) 法 により, 血中の抗 BP180 抗体 (IgG), 抗 BP230 抗 体 $(\mathrm{IgG})$ あるいは抗 VII 型コラーゲン抗体 $(\mathrm{IgG})$ を 検出する.

\section{C鑑別骖断}

以下の疾患を鑑別する。

表皮水疮症，虫刺症，喜麻疹様血管炎，ポルフィリン症， 多形紅斑, 薬疹, アミロイドーシス, 水疮型エリテマトー デス.

$\mathrm{A}$ : 臨床的診断項目, B : 検査所見, C : 鑑別診断の項目 のうち, 以下の(1)または2(2)を満たすものを類天疮瘡と診 断した。

(1)：Aのうち 1 項目以上かつ $\mathrm{B}-1$ かつ B - 2のうち 1 項目以上を満たし，Cの鑑別すべき疾患を除外した もの.

(2)：Aのうち 1 項目以上かつ B - 20 2 項目を満たし, Cの鑑別すべき疾患を除外したもの.

pean academy of dermatology and venereology のガイドラ イン ${ }^{6)}$ (表 1）に準じた。本研究での BP および MMPの 診断は，文献 1,2$)$ をとに当院皮膚科で用いられている基 準に従い行った(表 2)。

BP および MMP の抗原型は，ELISA 法にて BP180 に対 する自己抗体を検出した場合，または免疫ブロット法にて $180 \mathrm{kDa}$ の蛋白に対する自己抗体を検出した場合を BP180 型とした。また，BPでは免疫ブロット法にて $230 \mathrm{kDa}$ の蛋 白に対する自己抗体を検出した場合を BP230 型とした。さ らに，MMPの原因抗原は後述するように多岐にわたるた め $^{7)}$, 免疫ブロット法でも検出されなかった場合は不明型 とした(図 1). 
表 2 本研究における水疮性類天疮瘡と粘膜類天疮瘡の 診断基準

水疮性類天疮瘡 (Bullous pemphigoid: BP)

(1) 皮膚を主座とした水疮形成を認める.

(2) DIF および IIF にて基底膜部に IgG または補体の沈着 を認める。

(3) 抗 BP180NC16A 抗体 ELISA 法または免疫ブロット法 にて

血清中に BP180 または BP230 に対する自己抗体 (IgG) を検出する。

(1), (2), (3)をすべて満たすもの.

粘膜類天疮瘡 (Mucous membrane pemphigoid : MMP)

(1) 口腔粘膜を含む粘膜主体にびらんや水疮形成を認め る.

(2) DIF または IIF にて基底膜部に IgGの沈着を認める.

(3) 抗 BP180NC16A 抗体 ELISA 法または免疫ブロット法 にて

血清中に基底膜部蛋白に対する自己抗体（IgG）を検 出する.

(1)かつ(2), または(3)を満たすもの.

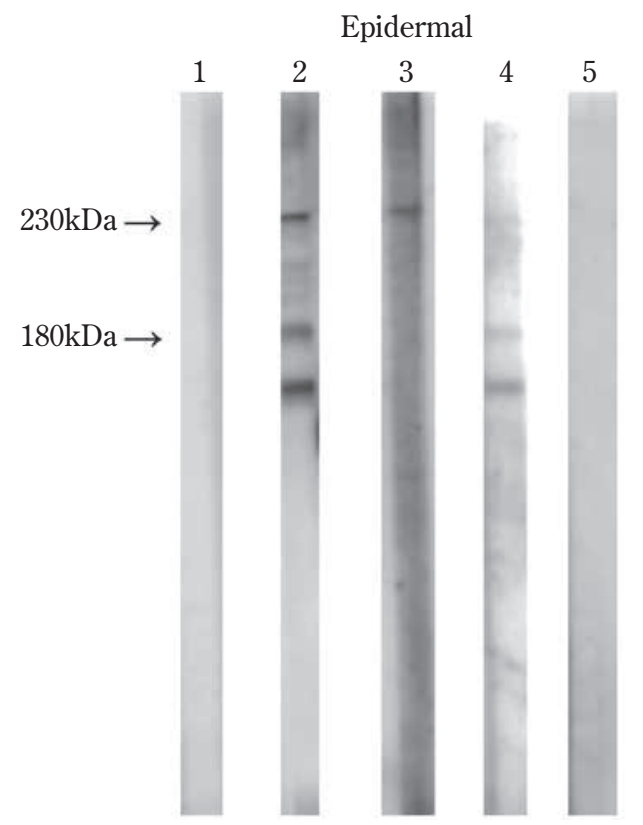

$1:$ 正常血清 (negative control)

2 : 水疮性類天疮瘡 (positive control)

3 : 症例 $4 \quad(\mathrm{IgG}) 230$ 型水疮性類天疮瘡

4 ：症例 7 （IgG） 180型粘膜類天疮瘡

$5 ：$ 症例 $14(\mathrm{IgG})$ 不明型粘膜類天疮瘡

図 1 正常ヒト表皮抽出液を用いた 免疫ブロット法の代表例

$230 \mathrm{kDa}$ の蛋白に反応する $\operatorname{IgG}$ 抗体が陽性（症例 4)， $180 \mathrm{kDa}$ の蛋白に反応する IgG 抗体が陽性（症例 7)， 反応なし (症例 14 ).
結

果

類天疮瘡と診断された 14 例の内訳は, BP 4 例（BP180 型 3 例, BP230 型 1 例), MMP 10 例 (BP180 型 6 例, 抗 原不明型 4 例) であった (表 $\mathbf{3 , 4})$.

\section{水疮性類天疮瘡（表 3)}

BP 4 例の性別は男性 1 例，女性 3 例であり，年齢は 42 歳から 72 歳 (中央值; 64 歳) であった。主な皮膚での発 症部位は体幹, 四肢であり, 歯肉, 煩粘膜, 硬口蓋のびら ん・水疮などの口腔粘膜病変は全例で併発しており, うち 2 例は口腔内に初発していた. ELISA 法による血液検査で は, 3 例が抗 BP180NC16A 抗体陽性であり, 病理組織学的 検査にて表皮下水疮を認めた症例は 3 例であった. DIF で は，3例（1例は検体不良）で IgG と C3 が陽性, IIF およ び ssIIFでは，4例全例で IgG 陽性の結果が得られた。当 科初診から診断確定および治療開始までの期間は 2 週間か ら4 か月であった。

治療内容は, 病変が比較的広範囲な中等度以上の 2 例に 対しプレドニゾロン (PSL) の全身投与, その他症状が軽度 であった 2 例でステロイド局所投与およびミノサイクリン (MINO) 内服およびアズレンスルホン酸ナトリウム $(\mathrm{AZ})$ 含嗽が実施された. PSLの全身投与前には, 免疫抑制に伴 い急性化の可能性がある口腔内感染源の有無を精査した。 皮膚科での投薬と併行し, 当科に打いても治療の効果や口 腔内に新たな病変の出現がないか, ステロイド軟膏使用中 の場合は口腔カンジダ症合併の評価を行い, 注意深く経過 観察した。口腔内びらんに伴う疼痛コントロール対策とし て局所麻酔薬配合含嗽剂使用や口腔清掃指導を行い, 全例 で症状改善を認めた。

\section{粘膜類天疱瘡（表 4)}

MMP 10 例の性別は, 男性 2 例, 女性 8 例であり, 年齢は 53 歳から 84 歳 (中央值；71歳）であった。全例で皮虞病変 の併発は認めず, 㐘肉, 煩粘膜, 軟口蓋を中心としたびらん, 潰瘍を認めた。受診経緯については，10 例中 7 例はかかり つけ柬科医院からの紹介であり, いずれも $\mathrm{AZ}$ 軟膏やステ ロイド軟膏塗布にて改善を認められないものや無治療のま ま紹介されていた。血液検査では，5例が抗 BP180NC16A 抗体陽性であり, 口腔粘膜組織標本による HE 染色下で上 皮下水疮が観察された症例は 5 例であった. DIF では，8例 で IgG, C3 または IgA 陽性, IIF では, 4 例が IgG 陽性であ った. SsIIFにて 4 例が表皮側に IgG 陽性であり，6例は陰 性であった。当科初診から診断確定および加療に至る期間 は, 非典型例で診断に難渋する例（症例提示, 表 4 , 症例 9 参照）もあったが，多くは 1 か月以内に治療が開始された。 
表 3 水疮性類天疮瘡の症例一覧

\begin{tabular}{|c|c|c|c|c|c|c|c|c|c|c|c|c|}
\hline \multirow[t]{2}{*}{$\begin{array}{l}\text { 症例 } \\
\text { 番号 }\end{array}$} & \multirow[t]{2}{*}{ 年歯令 / 性別 } & \multirow[t]{2}{*}{$\begin{array}{l}\text { 病悩 } \\
\text { 期間 } \\
\text { (か月) }\end{array}$} & \multirow[t]{2}{*}{$\begin{array}{l}\text { 皮膚 } \\
\text { 病変 }\end{array}$} & \multirow[t]{2}{*}{$\begin{array}{c}\text { 口腔内 } \\
\text { 病変 }\end{array}$} & $\begin{array}{c}\text { 血液検査 } \\
\text { (ELISA 法) }\end{array}$ & \multicolumn{2}{|c|}{ 蛍光抗体法 } & \multirow{2}{*}{$\begin{array}{c}\text { 免疫 } \\
\text { ブロット法 } \\
\text { 基質: } \\
\text { 正常ヒト表皮 } \\
\text { 抽出液 } \\
\text { (IgG) }\end{array}$} & \multirow{2}{*}{$\begin{array}{l}\text { 病理 } \\
\text { 組織像 } \\
\text { 表皮下 } \\
\text { 水疮 }\end{array}$} & \multirow[t]{2}{*}{ 抗原型 } & \multirow[t]{2}{*}{ 治療 } & \multirow[t]{2}{*}{ 経過 } \\
\hline & & & & & $\begin{array}{c}\text { 抗 BP180 } \\
\text { NC16A 抗体価 } \\
(\text { IgG) }\end{array}$ & DIF & $\begin{array}{c}\text { IIF } \\
\text { 最大希釈 } \\
\text { 倍率 } \\
\text { (IgG) }\end{array}$ & & & & & \\
\hline 1 & $42 / \mathrm{F}$ & 6 & $\begin{array}{l}\text { 体幹 } \\
\text { 四肢 }\end{array}$ & 蒾肉 & 26 & IgG, C3 & 320 & $180 \mathrm{kDa}$ & + & BP180 型 & $\begin{array}{c}\text { MINO } \\
\text { AZ }\end{array}$ & 改善 \\
\hline 2 & $66 / \mathrm{F}$ & 1 & 四肢 & 煩粘膜 & 52.4 & - & 40 & $180 \mathrm{kDa}$ & - & BP180 型 & PSL & 改善 \\
\hline 3 & $62 / \mathrm{M}$ & 2 & 四肢 & $\begin{array}{l}\text { 番肉 } \\
\text { (初発) }\end{array}$ & 70 & IgG, C3 & 40 & $180 \mathrm{kDa}$ & + & BP180 型 & $\begin{array}{l}\text { PSL } \\
\text { AZ }\end{array}$ & 改善 \\
\hline 4 & $72 / \mathrm{F}$ & 24 & $\begin{array}{l}\text { 体幹 } \\
\text { 頭皮 }\end{array}$ & $\begin{array}{l}\text { 硬口蓋 } \\
(\text { 初) }\end{array}$ & - & IgG, C3 & 160 & $230 \mathrm{kDa}$ & + & BP230 型 & MINO & 改善 \\
\hline $\begin{array}{l}\mathrm{C} 3 \\
\mathrm{AZ}\end{array}$ & $\begin{array}{l}\text { : 補体第 } 3 \\
\text { : アズレン }\end{array}$ & ルホ & & & $\begin{array}{r}\text { MINO : ミノ } \\
\text { PSL : プレ }\end{array}$ & $\begin{array}{l}\text { イクリン } \\
\text { ニゾロン }\end{array}$ & $\begin{array}{l}\text { 塩酸塩| } \\
\text { 内服 }\end{array}$ & & & & & \\
\hline
\end{tabular}

表 4 粘膜類天疮瘡の症例一覧

\begin{tabular}{|c|c|c|c|c|c|c|c|c|c|c|c|}
\hline \multirow[t]{2}{*}{$\begin{array}{l}\text { 症例 } \\
\text { 番号 }\end{array}$} & \multirow[t]{2}{*}{ 年齢 / 性別 } & \multirow[t]{2}{*}{$\begin{array}{c}\text { 病悩 } \\
\text { 期間 } \\
\text { (か月) }\end{array}$} & \multirow[t]{2}{*}{$\begin{array}{c}\text { 口腔内 } \\
\text { 病変 }\end{array}$} & \multirow{2}{*}{$\begin{array}{c}\text { 血液検查 } \\
\text { (ELISA 法) } \\
\text { 抗 BP180 } \\
\text { NC16A 抗体価 } \\
\text { (IgG) }\end{array}$} & \multicolumn{2}{|c|}{ 蛍光抗体法 } & \multirow{2}{*}{$\begin{array}{c}\text { 免疫 } \\
\text { ブロット法 } \\
\text { 基質： } \\
\text { 正常ヒト表皮 } \\
\text { 抽出液 } \\
\text { (IgG) }\end{array}$} & \multirow{2}{*}{$\begin{array}{l}\text { 病理 } \\
\text { 組織像 } \\
\\
\text { 上皮下 } \\
\text { 水疱 }\end{array}$} & \multirow[t]{2}{*}{ 抗原型 } & \multirow[t]{2}{*}{ 治療 } & \multirow[t]{2}{*}{ 経過 } \\
\hline & & & & & DIF & $\begin{array}{c}\text { IIF } \\
\text { 最大希釈 } \\
\text { 倍率 } \\
\text { (IgG) }\end{array}$ & & & & & \\
\hline 5 & $62 / \mathrm{F}$ & 24 & 㐘肉 & 14 & $\mathrm{IgG}, \mathrm{C} 3$ & - & $180 \mathrm{kDa}$ & + & BP180 型 & DEX & 改善 \\
\hline 6 & $59 / \mathrm{F}$ & 14 & 柬肉 & 21 & IgG, C3 & 20 & $180 \mathrm{kDa}$ & - & BP180 型 & $\mathrm{AZ}$ & 改善 \\
\hline 7 & $75 / \mathrm{M}$ & 12 & $\begin{array}{l}\text { 歯肉 } \\
\text { 軟口蓋 } \\
\text { 煩粘膜 }\end{array}$ & 32 & - & 20 & $180 \mathrm{kDa}$ & - & BP180 型 & $\begin{array}{c}\text { MINO } \\
\text { AZ }\end{array}$ & 改善 \\
\hline 8 & $84 / \mathrm{F}$ & 10 & 㐘肉 & - & $\operatorname{IgG}, \mathrm{C} 3, \operatorname{IgA}$ & 10 & $180 \mathrm{kDa}$ & - & BP180 型 & DEX & 改善 \\
\hline 9 & $67 / \mathrm{F}$ & 3 & $\begin{array}{c}\text { 歯肉 } \\
\text { 軟口蓋 }\end{array}$ & - & IgG, C3, IgA & - & - & + & 不明型 & PSL & 改善 \\
\hline 10 & $62 / \mathrm{F}$ & 2 & $\begin{array}{c}\text { 柬肉 } \\
\text { 煩粘膜 } \\
\text { (眼粘膜) }\end{array}$ & 76.9 & - & 40 & - & - & BP180 型 & $\begin{array}{c}\text { MINO } \\
\text { DEX }\end{array}$ & 改善 \\
\hline 11 & $65 / \mathrm{F}$ & 1 & 㐘肉 & - & $\mathrm{IgG}, \mathrm{C} 3$ & - & - & + & 不明型 & DEX & 改善 \\
\hline 12 & $78 / \mathrm{M}$ & 48 & 㐘肉 & - & $\mathrm{IgG}, \mathrm{C} 3$ & - & - & - & 不明型 & DEX & 改善 \\
\hline 13 & $53 / \mathrm{F}$ & 7 & 㐘肉 & 14.7 & $\mathrm{IgG}, \mathrm{C} 3$ & - & - & + & BP180 型 & DEX & 改善 \\
\hline 14 & $79 / \mathrm{F}$ & 48 & 軟口蓋 & - & $\mathrm{IgG}, \mathrm{C} 3$ & - & - & + & 不明型 & $\begin{array}{c}\text { PSL } \\
\text { AZ }\end{array}$ & 改善 \\
\hline
\end{tabular}

$\mathrm{C} 3$ ：補体第 3 成分 $\mathrm{DEX}:$ デキサメタゾン局所投与

MINO：ミノサイクリン塩酸塩内服ＡZ：アズレンスルホン酸ナトリウム含嗽ＰSL：プレドニゾロン内服

治療内容については，1 か月以上のステロイド局所投与 で効果がみられなかった難治性の 2 例に対し PSLの全身投 与, その他病変部が限局的で疼痛が軽度な 8 例にはステロ イド局所投与, MINO 内服打よび $\mathrm{AZ}$ 含嗽が実施され，BP
と同様に治療前の感染源精査や治療中の病変の変化および 合併症の有無等, 口腔内管理を継続し, 全例で症状改善を 認めた。 


\section{症 例 提 示}

水疮性類天疮瘡症例.

症例 $4: 72$ 歳, 女性.

主 訴：口内炎ができた。

既往歴：関節リウマチ。

現病歴：2012 年 7 月頃より口蓋粘膜のびらんを自覚した。 2014 年 2 月には, 腕や背中に掻痒感を伴う水疮形成を認め たが皮膚科を受診せず，近医茵科より精査依頼にて 2014 年 7 月，当科を紹介受診した。

処置および経過：初診時, 硬口蓋に軽度接触痛を伴うび らんを認めたが (写真 1A) , ニコルスキー現象は認めなかっ た。さらに背部皮膚の水疮は掻破によりびらんとなり，一 部に痂皮の形成がみられた (写真 18$)$ 。鑑別診断として, 尋常性天疮瘩, 水疮性類天疱瘡, 粘膜類天疮瘡が疑われた が，血液検查で抗 BP180NC16A 抗体および抗デスモグレイ ン 1 (Dsg1) 抗体，抗デスモグレイン 3 (Dsg3) 抗体は陰性 であった。当院皮膚科に診察依頼した後, 皮膚の水疮形成 は頭皮に拡大した（写真 $1 \mathrm{C}$ )。皮膚からの生検では表皮下 に水疮形成を認めた（写真 1D)。さらに, DIF で IgG，C3 陽性，IIF で IgG 陽性であり（写真 $1 \mathrm{E}, \mathrm{F}$ ），正常ヒト表皮 抽出液による免疫ブロット法にて, 血清中に表皮抽出液 中の $230 \mathrm{kDa}$ の蛋白に反応する自己抗体（IgG）を検出した (図 1). BP230 型水疮性類天疮瘡の確定診断のもと MINO $100 \mathrm{mg} /$ 日の内服を開始した。午の後, 皮膚打よび口腔粘 膜の病変は消失した。口腔内診査と口腔衛生指導を継続し， 2014 年 9 月から 2017 年 1 月にかけて, MINO 内服量を 75 $\mathrm{mg} /$ 日, $50 \mathrm{mg} /$ 日と漸減した。午の後も新たなびらんや水 疮の出現はみられず，経過良好である（写真 1G）。

粘膜類天疮瘡症例.

症例 9:67 歳, 女性.

主 訴：歯肉の痛み。

既往歴：B 型肝炎.

現病歴：2014 年 2 月, 上下顎㐘肉のびらんと擦過痛を自 覚し，ブラッシング困難となった。近医茵科を受診した後， 精査依頼で当科を受診した。

処置および経過：初診時, 上下顎㐘肉と軟口蓋にびらん を認めた（写真 $2 \mathrm{~A}, \mathrm{~B})$ ．臨床所見からは，尋常性天疱瘡や 粘膜類天疮瘡, 口腔扁平苔痽, 金属アレルギーが鑑別診断 として挙げられた。当科で行った金属パッチテストでは陰 性であり,血液検査でも抗 BP180NC16A 抗体陰性であった。 難治性口内炎の臨床診断となったが, 病態より自己免疫性 水疮症の可能性も完全には否定できず，さらなる追加検査 を行うため当院皮膚科へ診察依頼した，DIF，IIF は共に陰 性であり, 難治性口内炎や口腔扁平苔痽の治療に準じてス
テロイド含嗽を約 10 か月間使用するも症状改善はみられ なかった，再度皮膚科と協議し，茵肉から生検を行ったと ころ上皮下に一部裂隙形成と基底膜部の離開に伴うびらん を認め (写真 2C)，さらにDIFにて IgG，IgA 陽性，IIFで IgG 陰性が確認され（写真 2D, E)，粘膜類天疮瘡の確定診 断に至った.PSL $50 \mathrm{mg} /$ 日の内服を開始後 1 か月で症状の 改善を認めた。口腔内精査や口腔衛生管理を継続し, 2015 年 7 月から 2017 年 1 月にかけて PSL $5 \mathrm{mg} /$ 日に減量した。 口腔内に新たな病変の出現はみられず, 経過良好である（写 真 $2 \mathrm{~F}, \mathrm{G}$ ).

\section{考察}

類天疮瘡に対する今回の検討から，血液検査や生検のみ で確定診断に至ったのは，BP 75\%，MMP 50\%であったの に対し，蛍光抗体法ではBP 100\%，MMP 80\%で，確定診 断に打ける蛍光抗体法の有用性が示された（表 5).

類天疮瘔の口腔内病変としては, 典型的な水疮形成は少 なく, ニコルスキー現象を伴わない口腔粘膜の多発性潰瘍， びらんを認めることが多い ${ }^{8)}$. したがって難治性口内炎を はじめ，尋常性天疱㾑，口腔扁平苔痽，覀性腫瘍等との鑑 別が重要になる，尋常性天疮瘡では，血液検査にて細胞間 接着分子である Dsg1 または Dsg3 に対する自己抗体が検 出され，鑑別の指標となる。臨床所見から本疾患が疑われ た場合，口腔外科医は口腔粘膜疾患の鑑別診断を適切に行 い，皮膚症状の鑑別に関しては皮膚科に診察依頼すること で医科と連携を図り，診断を進めることが重要である。

類天疮瘡の骖断方法の 1 つとして, 本邦では 2007 年よ り，BP180NC16A に対する ELISA 法が保険診療に収載さ れた。本法は，少量の血清で自己抗体を定量的に検出でき ることからスクリーニング検査として有用であるが，そ の検出率は BP で $80 \%$ 程度 ${ }^{9)}$ であるのに対し, MMPで は $50 \%$ 程度 ${ }^{1)}$ と低值であり, 今回の検討でも同様の検出 率であった。MMPの自己抗体の検出率が低い理由とし て, MMPの血清抗体価が BP に比較して低い可能性や, ELISA 法では BP180の NC16A に対して抗原が設定されて いるのに対して，MMPでは BP180の の 末端を抗原とす ることが多いこと等が考えられる ${ }^{10,11)}$ 。したがって，血 液検査で陰性であっても本疾患をすぐに否定するのではな く，他の検査結果を踏まえて判断する必要があることを十 分理解しておくべきである。

類天疮瘡の病理組織学的所見としては，炎症細胞浸潤を 伴う表皮下水疮が特徴である ${ }^{12,13)}$ 。本研究の結果では, 6 例で標本の上皮欠落により診断が困難であった。類天疮㾑 患者の口腔粘膜採取はその脆弱性により非常に困難なこと が多い。しかし，正確な病理組織学的診断には，上皮と粘 

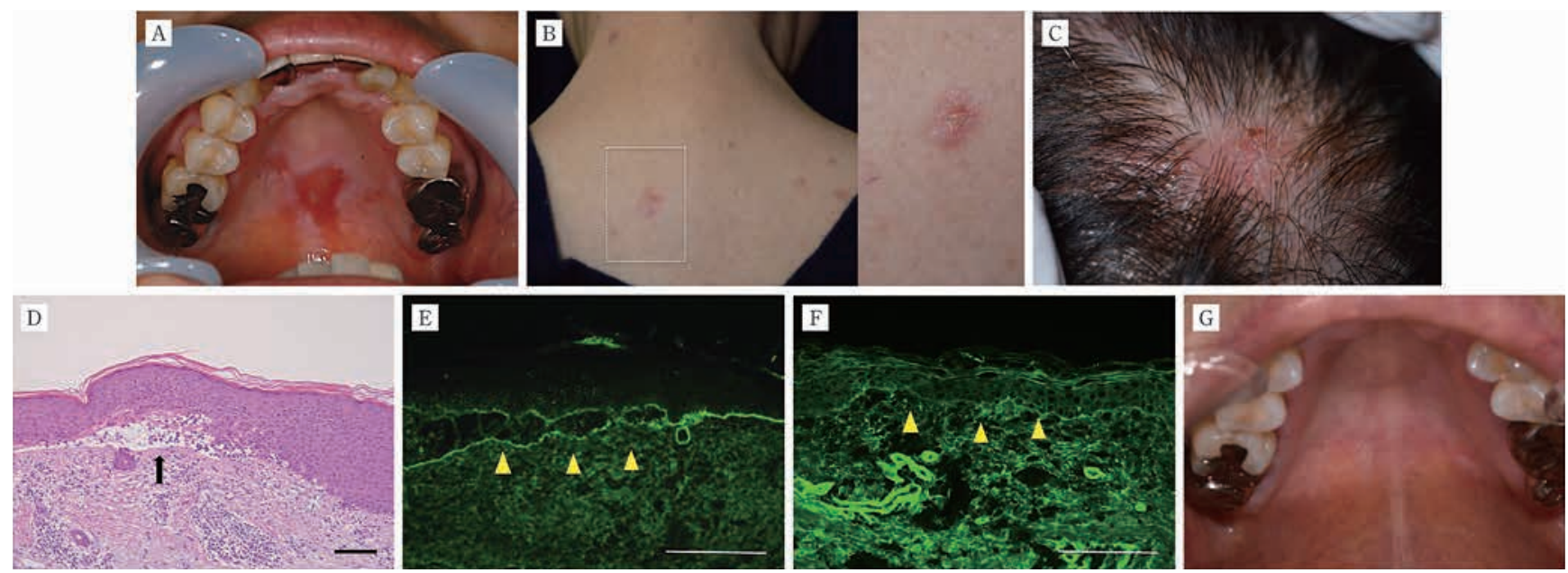

写真 1 水疮性類天疮瘡症例

A：初診時口腔内写真；硬口蓋粘膜にびらんを認める.

B , C : 皮膚写真 ；背部执よび頭皮に水疮搔破によるびらん形成がみられる。

D : 病理組織像 ；表皮下に水疮形成がみられる。(个) (HE 染色) (スケール：100 $\mu \mathrm{m}$ )

$\mathrm{E}$ ：蛍光抗体直接法 ; 表皮基底膜部に $\operatorname{IgG}$ の線状沈着を認める。（スケール：100 $\mu \mathrm{m}$ )

F : 蛍光抗体間接法 ; 血清 IgG 抗表皮基底膜部抗体の線状沈着を認める.（スケール：100 $\mu \mathrm{m}$ )

$\mathrm{G}$ ：治療後口腔内写真；硬口蓋粘膜のびらんは消失している.
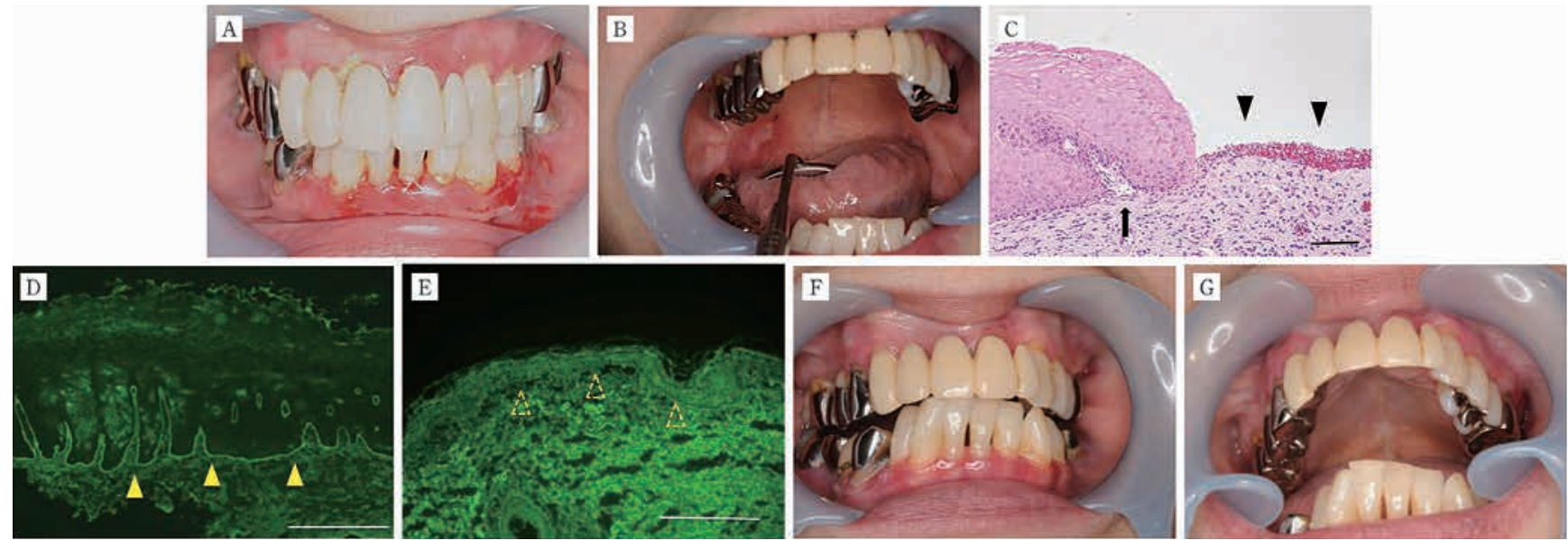

写真 2 粘膜類天疮瘡症例
A , B : 初診時口腔内写真; 下顎㐘肉および軟口蓋粘膜にびらんと出血を認める.

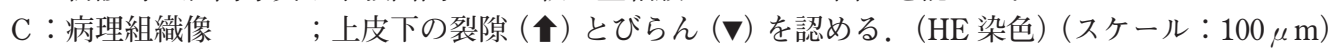
$\mathrm{D} ：$ 蛍光抗体直接法 ；表皮基底膜部に $\operatorname{IgG}$ の線状沈着を認める。（スケール：100 $\mu \mathrm{m}$ )
$\mathrm{E}$ ：蛍光抗体間接法 ; 表皮基底膜部に血清中抗表皮基底膜部抗体の沈着は認めない。(スケール：100 $\mu \mathrm{m}$ )
$F, G$ : 治療後口腔内写真; 㐘肉および軟口蓋のびらんや出血の改善がみられる.

膜下組織が確実に採取されている必要があり，組織の挫滅 を最小限にするよう慎重な手技や配慮を要する。

蛍光抗体法による免疫学的診断は類天疱瘡の確定診断に 非常に有用である。 BPでは，一般にDIF および IIFとも に IgG 陽性となる場合が多く ${ }^{2)}$, 本研究の結果でも 3 例
で DIF，IIFともに IgG陽性であった。一方で，MMPで は DIF は IgG 陽性であるが IIF では IgG 陰性となる場合 が多く ${ }^{1)}$ ，本研究の結果に扔いても DIF では 80\%, IIF で は 40\%で IgG 陽性であった. 患者の血清を使用する IIF で は, MMP 患者の血清抗体価が低值であることにより検出 
表 5 免疫学的検査および病理組織学的検査の陽性率

\begin{tabular}{llcc}
\hline & & 水疮性類天疮痆 (4 例) & 粘膜類天疮瘡 (10 例) \\
\hline 血液検查 (ELISA 法) & 抗 BP180NC16A (IgG) & $75 \%(3 / 4$ 例) & $50 \%(5 / 10$ 例) \\
䖝光抗体法 & DIF (IgG, IgA, C3) & $75 \%(3 / 4$ 例) & $80 \%(8 / 10$ 例) \\
& IIF (IgG) & $100 \%(4 / 4$ 例) & $40 \%(4 / 10$ 例) \\
免疫ブロット法 & 基質：正常ヒト表皮抽出液 (IgG) & $100 \%(4 / 4$ 例) & $40 \%(4 / 10$ 例) \\
病理組織学的検査 & 表皮下または上皮下水疮を認める & $75 \%(3 / 4$ 例) & $50 \%(5 / 10$ 例) \\
\hline
\end{tabular}

率が低下する可能性が考えられる ${ }^{10)}$ 。 また, 症例提示し た MMP症例（症例 9）のように, 初期にはDIF, IIF とも に陰性の場合でも，病状進行に伴う再検査にて陽性となる 場合もあることから，経過観察を行い，必要に応じて再度 検査の必要性を患者に説明し, 診断に結びつける態度が重 要である.

皮膚打よび口腔粘膜両者に病変を認める場合, BP と MMPの鑑別が困難な場合もある ${ }^{8)}$ 。しかし，口腔内に

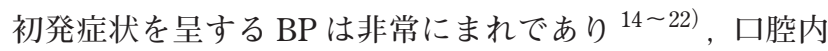
に初発したとしても皮膚症状を主体とし，自覚症状抢よ び他覚所見ともに粘膜症状は軽度である ${ }^{8)}$. BP の主な自 己抗原は BP180 の NC16A または BP230である ${ }^{2}$ ）。一方， MMPの病変の主座は, 口腔や眼の粘膜である ${ }^{23)}$. BP と 異なり自己抗原として Laminin332, Integrin $\alpha 6, \beta 4$ な ども含まれ，BP230 はほとんどみられない 2 (4). 本研究 では BP と MMPの鑑別診断は, 臨床所見に加え, DIF や IIF，ELISA，免疫ブロット法の結果をもとに行った。

本研究の結果では，罹病期間が長い症例に対しても，ほ ぼ全例で初診から 1 か月以内に確定䛦断を行うことがで き，早期治療が開始されていた。当院での蛍光抗体法等の 追加検查は皮膚科との連携により迅速に行われている。病 悩期間の短縮や円滑な治療導入のためにも医科との連携に よる検査・診断は有用であると考えられる。

類天疮瘡の治療は，中度から重症例では PSLの全身投 与 $(1 \mathrm{mg} / \mathrm{kg} /$ 日) やシクロフォスファミドやダプソン等の 免疫抑制剂の使用，血漿交換療法や大量ガンマグロブリン 療法の併用，軽症例ではデキサメタゾン (DEX) などステ ロイドの局所投与, テトラサイクリンとニコチンアミド併 用療法や MINO 内服が行われている ${ }^{5,24,25)}$ 。これらの高 用量のステロイド投与や㐘科適応のない薬剤の使用は医科 との連携が必要になり，さらに合併症への配慮が必要であ $3^{26)}$. とくにステロイド投与前の口腔内感染源の精査や， ステロイド軟膏使用中の口腔カンジダ症の合併症予防は口 腔外科医の重要な役割の 1 つである。また, 口腔内病変は 口腔清掃時の疼痛を伴うことも多く，炎症細胞浸潤により

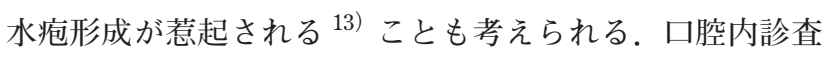
を継続し, 治療効果の判定や必要な軟膏や含嗽剤の選択, 口腔衛生状態の維持に努めることで全例での症状改善に貢 献できたと考えられる.

BP では悪性腫痬の合併が $5.8 \%$ と高率で認められるとい う報告もある ${ }^{27)}$ 。また MMPでは, 眼粘膜病変は視力低 下や失明の危険性があり，さらにLaminin332 型の MMP では悪性腫瘍の合併も多いとされる ${ }^{4)}$ 。重度合併症を考慮 すると，本疾患の病態を熟知することが求められる.

\section{結語}

今回われわれは，類天疮瘡の診断には他の口腔粘膜疾患 との鑑別診断の他，DIF，IIF 等の追加検査が重要である ことを示した。口腔外科医として本疾患の臨床所見や検査 所見, 病態を熟知し, 診断・治療を行うことが重要である.

謝辞

稿を終えるにあたり，本症例の診断・治療に関して多大なる ご協力を賜りました北海道大学皮膚科学教室 清水宏教授执よ び岩田浩明先生に深く御礼申し上げます。

本論文の要旨は第 70 回 NPO 法人日本口腔科学会学術大会 (2016年 4 月，博多）に打いて発表した。

本論文に関して，開示すべき利益相反状態はない.

\section{引用文献}

1) Murrell DF, Marinovic B, et al : Definitions and outcome measures for mucous membrane pemphigoid: Recommendations of an international panel of experts. J Am Acad Dermatol 72: 168-174, 2015.

2 ) Schmidt E, Zillikens D, et al : Pempigoid diseases. Lacet 381: 320-332, 2013.

3 ) Wada M, Sato J, et al : Anti-BP180-type mucous membrane pemphigoid: report of two cases. Odontology. 104: 114-118, 2016.

4 ) Hayakawa T, Furumura M, et al : Diagnosis of oral 
mucous membrane pemphigoid by means of combined serologic testing. Oral Surg Oral Med Oral Pathol Oral Radiol 117: 483-496, 2014.

5 ) Barnadas MA, Gelpi C et, al : Repeat direct immunoflourescwnc (DIF) test, using, 1M NaCL treated skin, in the supepidermal autoimmune bullous diseases that contain IgG at the dermal epidermaljunction. J Cutan Pathol 26: 37-41, 1999.

6 ) Feliciani C, Joly P, et al : Management of bullous pemphigoid : the European Dermatology Forum consensus in collaboration with the European Academy of Dermatology and Venereology. Br J Dermatol. 172: 867-877, 2015.

7 ) Xu HH,Werth VP et al : Mucous membrane pemphigoid. Dent Clin North Am 57: 611-30, 2013.

8 ）宮本重樹, 金子忠良, 他：水疮性類天疮瘡と鑑別困 難であった抗 BP180 型粘膜類天疮瘔の 1 例. 日口 外誌 58: 297-301, 2012.

9 ) Lee EH, Kim YH, et al : Usefulness of Enzyme-linked Immunosorbent Assay Using Recombinant BP180 and BP230 for Serodiagnosis and Monitoring Disease Activity of Bullous Pemphigoid. Ann Dermatol 24: 45-55, 2012.

10) Taylor J, McMillan R, et al : World Workshop on Oral Medicine VI: A systematic review of the treatment of mucous membrane pemphigoid. Oral Surg Oral Med Oral Pathol Oral Radiol 120: 161-171, 2015.

11）古賀浩嗣, 石井文人, 他：保険収載されている自己 免疫性水疮症の検查法：抗デスモグレイン 1 抗体, 抗デスモグレイン 3 抗体，抗 BP180 抗体. Mod Media 59: 297-302, 2013.

12) Kneisel A, Hertl M, et al : Bullous pemphigoid-diagnosis and therapy. Wien Med Wochenschr 164: 363371, 2014.

13) Iwata H, Kitajima $Y$, et al : Bullous pemphigoid : Role of complement and mechanisms for blister formation within the lamina lucida. Exp Dermatol 22: 381-385, 2013.

14) Mohan KH, Pai S, et al : Techniques of immuno- flourescence and their significance. Indian J Dermatol 74: 415-419, 2008.

15) Brick KE, Weaver $\mathrm{CH}$, et al : Incidence of bullous pemphigoid and mortality of patients with bullous pemphigoid in Olmsted County, Minnesota, 1960 through 2009. J Am Acad Dermatol 71: 92-99, 2014.

16）川島愛雄, 石倉多美子, 他：水疮性類天疮瘡 29 例の まとめと予後調査。西日皮 39: 37-45, 1977.

17）小林博人, 田辺俊英, 他: 瘏痕性類天疮瘡, 水疮性 類天疮瘡に対するニコチン酸アミド大量療法. 皮膚 32: 240-244, 1990.

18）櫻井一成, 高橋由美子, 他：口腔粘膜に初発した水 疮性類天疮瘡の 1 例。 日品外誌 38: 518-519, 1992.

19）野中玲子, 小坂和己, 他: 口腔粘膜病変で発症した 水疮症の 2 例. 耳鼻臨床 91:273-280, 1998.

20）高岡一樹, 萬野幸代, 他：口蓋粘膜に生じた水疮性 類天疮瘡の 1 例。 日口外誌 50: 672-675, 2004.

21）伊藤大典, 豊田 華, 他：口腔内に初発した水疮性類 天疮瘡の 1 例. 日口粘膜誌 $12: 30-36,2006$.

22) 渡辺 彩, 早乙女敦子, 他: 水疮性類天疮瘡口腔粘 膜に初発した症例. 皮病診療 30: 389-392, 2008.

23) Hayasi I, Shinkuma S, et al : Mucous membrane pemphigoid with generalized blisters : IgA and IgG autoantibodies target both laminin-332 and type XVII collagen. Br J Dermatol 166: 1116-1120, 2011.

24) Ogawa $\mathrm{H}$, Sakuma $\mathrm{M}$, et al : The incidence of internal malignancies in pemphigus and bullous pemphigoid in Japan. J Dermatol Sci 9: 136-141, 1995.

25) Criteria D, Factors $P$, et al : The First International Consensus on Mucous Membrane Pemphigoid. 138, 2010.

26）笹井 収, 浅野雅之, 他: 水疮性類天疮瘡の予後解 析みやぎ県南中核病院を受診した高齢水疱性類天疱 患者 52 症例に打ける生存期間と予後因子の統計学 的検討. 日皮会誌 125: 235-241, 2015.

27) Pfütze M, Niedermeier A, et al : Introducing a novel Autoimmune Bullous Skin Disorder Intensity Score (ABSIS) in pemphigus. Eur J Dermatol 17: 4-11, 2007. 